\title{
Development of Interactive Physics E-Module Using the SETS (Science, Environment, Technology, Society) Approach to Improve Science Literacy Dimension of Content and Process Dimensions in Fluid Dynamics Material
}

\author{
Eka Syafutri *, Widodo, and Yudhiakto Pramudya \\ Master Program of Physics Education, Universitas Ahmad Dahlan \\ Jl. Pramuka No. 42, Yogyakarta, Daerah Istimewa Yogyakarta, Indonesia \\ *Email: ekasyafutri@gmail.com
}

\begin{tabular}{ll}
\hline \multicolumn{1}{c}{ Article Info } & \multicolumn{1}{c}{ ABSTRACT } \\
\hline $\begin{array}{l}\text { Article History } \\
\text { Received Feb 8, 2020 }\end{array}$ & This development research produces interactive physic electronic products using the \\
Revised Apr 23, 2020 & $\begin{array}{l}\text { interactive physics SETS approach (Science, Environment, Technology and Society) } \\
\text { in terms of presenting the components of illustration, language, and the suitability of } \\
\text { the material. The validity results of the electronic module carried by experts and }\end{array}$ \\
\hline Keywords: & teachers develeop the average yield of 96.36\% so it is feasible to use. The study \\
Dynamic fluid & design is pretest-posttest control group to see the improvement of literacy dimension \\
E-Module & process. Subject of the study consisted of two groups: the experimental group and the \\
Science literacy & control group. The data collection formed by science literacy of dimension content \\
SETS & and process is analyzed using MANOVA with significance level of 5\%. The results \\
showed that the electronic module using SETS approach significantly influence the & improvement of science literacy dimension content and process.
\end{tabular}

To cite this article:

E. Syafutri, Widodo, and Yudhiakto Pramudya, "Development of Interactive Physics E-Module Using the SETS (Science, Environment, Technology, Society) Approach to Improve Science Literacy Dimension of Content and Process Dimensions in Dynamic Fluid Material," Indones. Rev. Phys., vol. 3, no. 1, pp. 11-18, 2020.

\section{Introduction}

The development of technology for the 21 st-century has brought a great influence on the development of education in Indonesia. The rare Indonesia conditions nowadays is that the number of human resources can follow the progress of science and technology optimally. To create quality human resources education courses closely related to the role in the delivery of the next generation that can compete internationally for education contribute greatly to prepare cadres of the nation. Subiantoro [1] suggested that the need for capital generation of scientific literacy be able to apply their knowledge and contribute to the development of science and technology to improve people's welfare. The relevance of education issues was confirmed by the United Nations when declared, between 2005 and 2014 about a decade of education for sustainable development. Attitudes toward the new challenges of the post-industrial society is a direct consequence of the development of science and technology, the explosion of knowledge and globalization [2].

On the curriculum in 2013, one of the teacher's job is to maximize the learning process. Learning approach Science, Environment, Technology, Society (SETS) is one of the lessons according to the curriculum of 2013. SETS is an integrated approach involving elements of science, technology, and society. This approach aims to help students seeing science, development, environmental influences, technology, and society as a reciprocal [3]. In SETS learning approach, students are expected to connect the four elements SETS with the material being studied. Students practice in a way that varies from observing, discussing, asking, answering, and solving problems.

A Meaningful science learning process for students can be obtained if students have good literacy skills. Miller (1998) in [4] argued that scientific literacy can also be defined as the ability to read and write about science and technology. The definition of scientific literacy is looking at multi-dimensional scientific literacy in this aspect of the measurement, like the content of science, the process of science, and the science application context. Thus, students can use scientific knowledge and can apply it to solve everyday problems related to the material studied [5]

Toharudin, Hendrawati, and Rustama [6] suggested that the process of science is the ability of students to use scientific knowledge and understanding in answering a question or solve a problem. Low ability students' science literacy in particular on the dimensions of the process can be seen in 2015 that Indonesia increased particular scores in ability of science. However, the latest results of PISA 2018 published The Organization for Economic Cooperation and Development (OECD), Indonesia still scored below the average of the standards set in which data PISA showed about $40 \%$ of Indonesian students reached level two for the ability of science. This again shows the level of Indonesia is still below the average for OECD defined science capability that is $78 \%$ [7].

Computer-based instruction learning to have significant benefits in the learning process. The 
utilization of computer can serve as a tool in learning process, while as tutor implies that the computer replaces the role of teachers in teaching, presenting information, testing through questions and give feedback as learning program or involve students in the simulation or game [8]. Therefore, the electronic module (E-module) is an option that is currently supporting the development of 21st-century learning since conventional learning (print modules) less interactive and static forms or monotonous. the study of physics needs a media that can support the mastery of the concepts of physics, especially in the dynamic fluid material.

Under the conditions described above, the development of a media-based interactive learning computer technology supports the science literacy approach SETS as an alternative learning media that can be used by teachers and students. Some similar research to develop e-learning using the e-module has been done. The research is still confined to media development and effective use of the media only. This research is more emphasis on measuring the dimensions increased scientific literacy approach process SETS to develop modules nonprinting.

\section{Theory}

Rahdiyanta [9] revealed that the module is one form of instructional materials packaged as a whole and systematical are contained within a load a set planned learning experiences and is designed to help learners master the specific learning objectives.

The rapid development of technology today has allowed the computer to load and deliver various forms of media in it. In this case, Heinich, Molenda \& Russel (1996) in [7] argues that:

"... it has the ability to control and integrate a wide variety of media still pictures, graphics, and moving images, as well as printed information. The computer can also record, analyze, and react to student responses that are typed on a keyboard or selected with a mouse ".

The development of information media is now beginning to transit from print media gradually turning to digital media. Presentation materials are not only limited to the print media itself, but already take advantage of digital media. One form of such a presentation is an ebook. Borg and Gall [9] stated that electronics module (E-module) is a good development of teaching materials since printed modules is less interactive and has a display static images or monotone while e-modules can be interactively present the material displayed by multimedia such as video, animation, simulation and provide direct questions with feedback.

The function of the media in the learning process is important in improving the quality of the learning process that supported by the selection of methods or models of learning appropriate to achieve good learning outcomes in this regard is to increase science literacy dimension of the process. Electronic modules development in this study using the SETS approach which has 5 stages of learning as a guide to learners in the learning process and is expected to increase the motivation to learn about physics.

Binadja [3] stated vision SETS is a way of looking into the future, lead to an understanding that everything in life contains aspects of science, environment, and society influence each other mutually. SETS learning leads to a way of thinking about science, how to investigate, and its interaction with the environment, technology, and society. The purpose of education is to form SETS visionary individuals who have a science and technology literacy and has a concern for the community and environment. Someone who has a science and technology literacy can solve problems using scientific concepts following the material at each level of education,

Based on the above description that the purpose SETS approach is teachers are required to transfer knowledge to students contextually where the situation and given the concept of learning can be packaged into the form of technology and then the students are required to determine the role of these technologies to the public.

Scientific literacy is a person's ability to distinguish the facts of science from a variety of information, identify and analyze the use of methods of scientific investigation as well as the ability to organize, analyze, interpret clicking quantitative data and information science [10].

Lederman [11] states that the essential nature of the scientific literacy of students roommates influences decisions about personal and societal problems. Beyond this, however, educators work to influence Students ability to view science through a more holistic lens. Scientific literacy becomes fundamental because it can affect students in decision-making when faced with social and personal problems [11]. Arohman [2] revealed that a man who has the scientific literacy has to assess the science process skills in making daily decisions when dealing with other people, society and the environment, including social and economic development.

In contrast to that presented by Hoolbrook competence and Rannikmae, PISA 2015 assessment of science literacy outlining Figure 1.

Competence in science literacy refers to the process of science involved when answering a question or solve a problem, such as identifying and interpreting evidence and explain the conclusions. The following scientific literacy competence based on three aspects named content, process, and context that are presented in the table.

By following the above presentation, learning by applying the approach SETS is a process to build on the four foundations of scientific literacy, such as: (1) the foundation SETS, build an understanding of the nature of science and technology, the relationship of science and technology, as well as the social and environmental context of science and technology; (2) the foundation of knowledge, building knowledge and understanding of science and apply this understanding to interpret, 
integrate, and develop knowledge; (3) the foundation of skills, build the skills necessary to conduct inquiry of science and technology, communicate ideas and scientific results, cooperate and make decisions; (4) the foundations of attitudes/societal value.

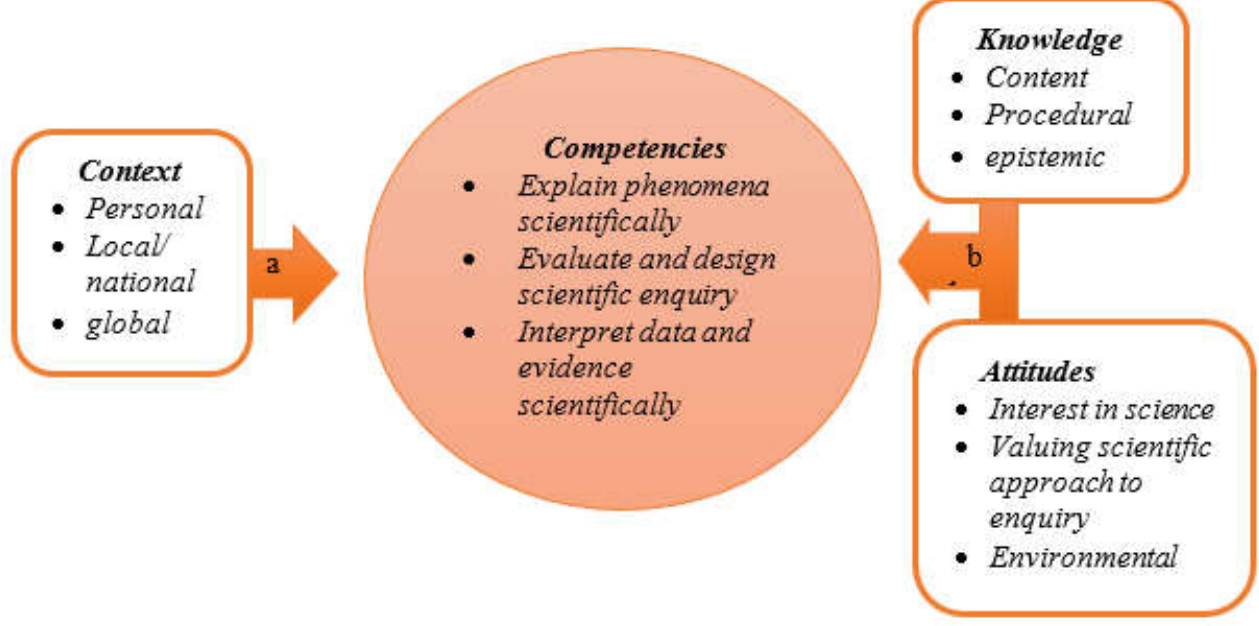

Figure 1. Framework for PISA 2015 assessment of science literacy [7]

Based on the statement, it can be said that the SETS approach is able to compensate for the learning process of students to see the students' science literacy skills improvement in developing instruments that refer to syntax SETS approach to science literacy achievement indicators in particular to the dimensions of content and process. This is in line with the dynamic fluid material on its application widely used to support the work of man.

Electronic Module development with dynamic fluid material is expected to improve the scientific literacy of students as prepared based on the competencies that match the dimensions of the scientific literacy and science process approach adapted to the stage SETS syntax. The module is based on the concepts of dynamic fluid as well as events in the daily life of students related to the dynamic fluid. This is in line with the process of learning to use the SETS approach as a review to see the students' science literacy skills improvement.

\section{Method}

This development study producesinteraktive emodul product using adobe flash with ADDIE development module, that has five steps: Analysis, Design, Development, Implementation, and Evaluation. The research design used pretest-posttest control group design [12]. This study consisted of the experimental group using e-modules and development results in the control group that applies classroom learning to use the textbook and worksheets.

Before performing the application of the product to see the students' science literacy dimension of the process, some early stage of the analysis phase of the method is students needed to begin learning the used of curriculum. After conducting an analysis followed by a design phase, make the lattice e-module before being developed following the storyline created. The instrument used to look at the process of the scientific literacy dimension of the pretest-posttest shaped description were analyzed using N-Gain and observation sheet to see the learning process of the student.

The following equation N-Gain, [13]:

$$
\mathrm{N} \text {-gain }=\frac{S_{\text {post }}}{S_{\text {maks }}}-\frac{S_{\text {pre }}}{S_{\text {pre }}}
$$

Where:

$S_{\text {post }}=$ Score posttest

$S_{\text {pre }}=$ Score pretest

$S_{\max }=$ Maximal ideal Score

Table 1. Criteria for the change scores of students before and after the learning, [13]

\begin{tabular}{cc}
\hline Score range & Information \\
\hline$>0.7$ & High \\
$0.3 \leq \mathrm{g} \leq 0.7$ & moderate \\
$<0.3$ & Low \\
\hline
\end{tabular}

The Manova test as a prerequisite test analysis to see the connection between e-modules to increase the science literacy development dimension of the process.

\section{Results and Discussion}

After conducting three phases of analysis: a preliminary analysis, environmental analysis and the analysis of students' school, then followed the design of instruments to be used by following needs that have been previously analyzed.

After analysis, the storyline and flowchart design are done in advance as a reference during the development stage. The development of the e-module flowchart is described in Figure 2. 
After preparing the storyline, we develop the syllabus and lesson plans that are used as a reference for the manufacturing process of learning and assessment instruments. The development result of the storyline is formed of interactive e-module physics. The product consists of a dynamic fluid material, Animation proponents of the theory, simulation, and experiment PhET Interactive Exercises. The results of product development can be shown in the following Figure 3 to 6 :

1. Intro page

Intro page functioned as the first page that appears when the e-module is executed. Users enter a name for the access to the main menu page. Intro page can be seen in Figure 3.

2. The main menu page

On the main menu page will be displayed 6 menus named, Basic Competencies and Indicators, Material Fluid dynamic simulations PhET, Regarding figures, glossary and details. you can click The sixth menu to access the next page. The main menu page can be seen in Figure 4.
3. Weather Content

Maps of the material consist of four Chapters, named, Fluid Ideal, Legal Bernoulli, Bernoulli Law Enforcement and Training Menu. Sub-chapters in the application of Bernoulli's Law, named, Theorem Torricelli, Pipes, Venturimeter, Pitot tubes, Style Lift Aircraft and Application of Bernoulli's Law in everyday life. Weather exercises consist of two sessions: exercises 1 and exercises 2 . The user will be given the processing time 5-15 minutes to complete one matter. Users will switch to the next question, after the user has completed the number of the previous problem. Sample page layer can be seen in Figure 5 and Figure 6.

The results of the e-module products validation are carried by 2 validator experts and two teachers of physics. Content expert validation results can be seen in the Table 2.

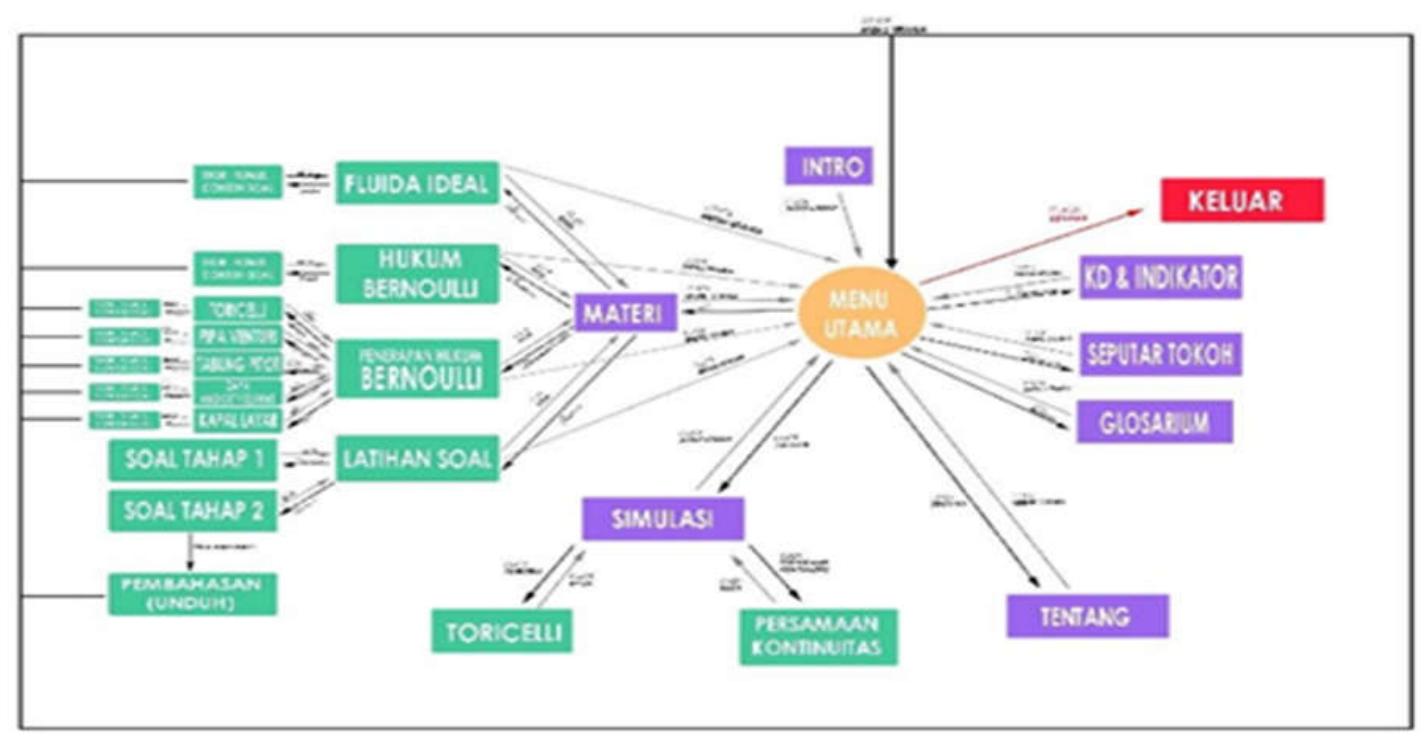

Figure 2. Flow diagram interface e-module 


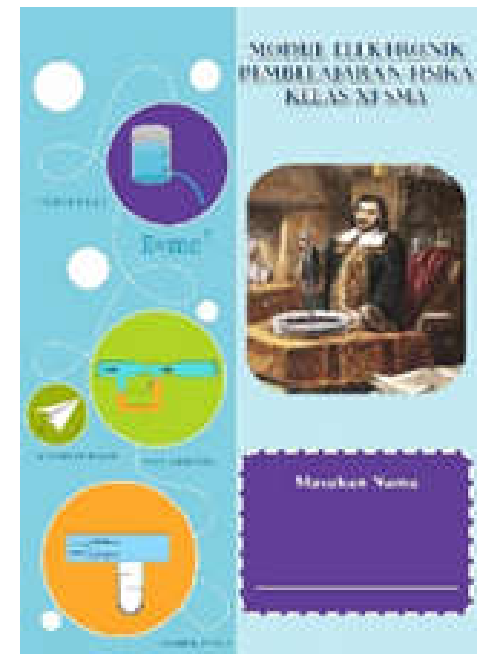

Figure 3. Intro page

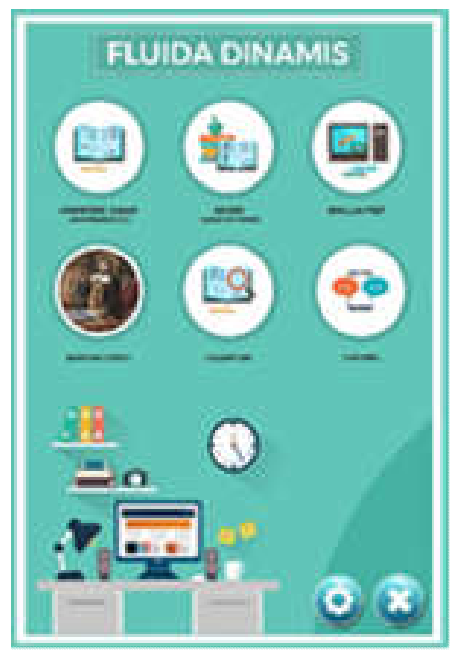

Figure 4. Main menu page

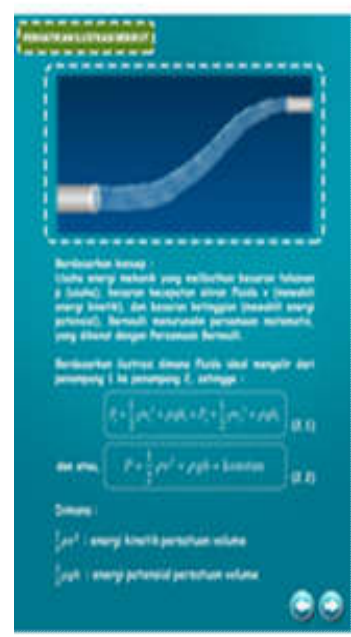

(a)

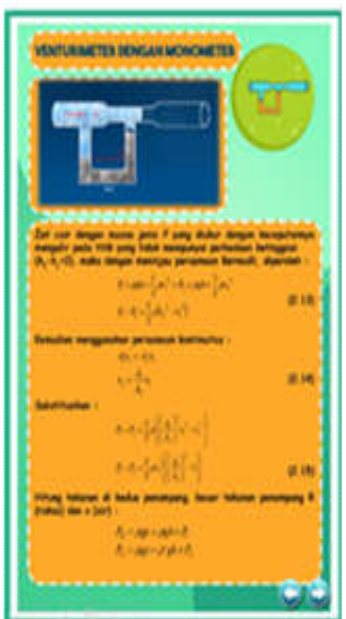

(b)

Figure 5. (a) Content page Bernoulli, (b) Content page Venturimeter

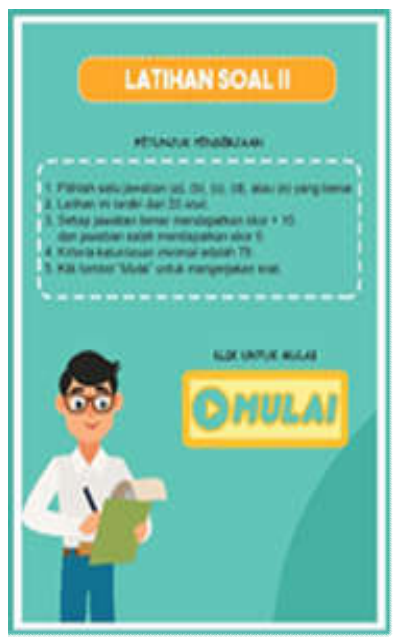

(a)

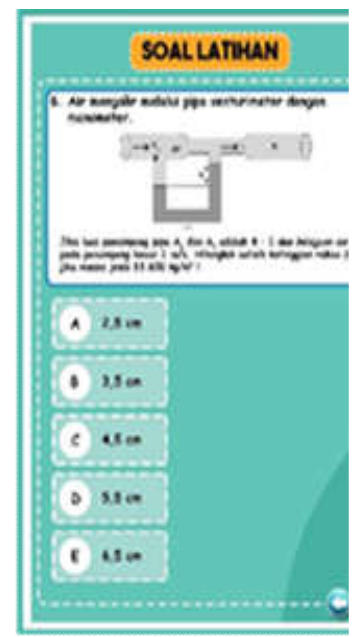

(b)

Figure 6. (a) Instructions page Exercises, (b) Exercises page

Table 2. Results of the validation of product quality by content expert

\begin{tabular}{cccccc}
\hline \multirow{2}{*}{ Aspects Rating } & \multicolumn{2}{c}{ Validators } & \multirow{2}{*}{ Average per aspects } & \multirow{2}{*}{ Category } \\
\cline { 2 - 3 } & \multicolumn{2}{c}{ 2 Lecturer } & 2 Teachers & & 3.79 \\
Contents & 3.71 & 3.56 & 3.56 & 3.56 & VG \\
Presentation & 3.44 & 3.50 & 3.47 & VG \\
Languange based BSNP & 3.67 & 3.94 & 3.81 & VG \\
SETS & $\mathbf{3 . 5 9}$ & $\mathbf{3 . 7 0}$ & & VG \\
\hline Average & \multicolumn{2}{c}{$\mathbf{3 . 6 5}$} & \multicolumn{2}{c}{ Very Good } \\
\hline
\end{tabular}

The percentage is calculated based on Table 2 . Agreement with the acquisition of $97.82 \%$ so that the product can be said to be reliable. In addition to ratings. media experts provide advice and input as an improvement to the product.
The tests is conducted by expert lecturers and two physics teachers to assess the electronic module of the aspects of screen design, easy of use, consistency, formatting function keys, usefulness, and graphic aspect. Media expert validation results can be seen in Table 3 . 
Table 3. Results of the validation of product quality by media experts

\begin{tabular}{|c|c|c|c|c|}
\hline \multirow{2}{*}{ Aspects Rating } & \multicolumn{2}{|c|}{ Validators } & \multirow{2}{*}{ Average of aspect } & \multirow{2}{*}{ Category } \\
\hline & 2 Lecturer & 2 Teachers & & \\
\hline Design of Screen Display & 3.33 & 3.67 & 3.50 & $\mathrm{VG}$ \\
\hline Ease of use & 3.40 & 3.80 & 3.60 & VG \\
\hline Consistency & 3.67 & 3.67 & 3.67 & VG \\
\hline Format & 3.75 & 3.75 & 3.75 & VG \\
\hline Expediency & 4.00 & 4.00 & 4.00 & VG \\
\hline Graphic Aspects & 3.38 & 3.63 & 3.50 & VG \\
\hline Average & 3.59 & 3.75 & \multirow{2}{*}{\multicolumn{2}{|c|}{ Very Good }} \\
\hline Average 4 validators & & & & \\
\hline
\end{tabular}

The result of media experts and subject matter experts to draft the first module which has been revised by the input of experts. Furthermore. the draft module II trials conducted on a limited basis (preliminary field testing) to 10 students of class XII to see the response of students and produced the third draft that will be used in field tests (main field testing).

Limited trial (preliminary field testing) to 10 students of class XII students to see the response to the emodule. Limited test results can be seen in Table 4 .

Table 4. Student response data to the e-module physics

\begin{tabular}{cccc}
\hline Assessment Criteria & Score & Score & Category \\
\hline Presentation Materials & 23.5 & A & Very good \\
Linguistic & 9.60 & A & Very good \\
Graphic & 24.6 & A & Very good \\
Components SETS & 16.9 & A & Very good \\
\hline
\end{tabular}

The Table 4 shows the results of qualitative data conversion to quantitative students to look at the feasibility modules in a limited test (preliminary field testing). Based on the results of expert validation data and student responses on a limited test indicates that the emodule interactive physics using the SETS approach suitable as alternative teaching materials to improve students' science literacy dimension of the process.
After conducting a limited test. then the test field (main field testing) aims to look at the effect of emodules to increase students' science literacy skills of the dimensions content and process. Pretest-posttest assessment data of students in field trials in the experimental group and the control group are shown in Table 5 and 6.

Table 5. Pretest-posttest assessment data capability content dimension of science literacy

\begin{tabular}{|c|c|c|c|c|}
\hline \multirow{3}{*}{ Description } & \multicolumn{2}{|c|}{ Experiment Group } & \multicolumn{2}{|c|}{ Control Group } \\
\hline & Pretest & Posttest & Pretest & Posttest \\
\hline & \multicolumn{2}{|c|}{ Content } & \multicolumn{2}{|c|}{ Content } \\
\hline Mean & 16 & 72 & 12 & 53 \\
\hline Standard deviation & 2.89 & 17.64 & 6.93 & 19.64 \\
\hline Maximum value & 20 & 95 & 20 & 90 \\
\hline Minimum value & 15 & 50 & 0 & 20 \\
\hline $\begin{array}{l}\text { Gain } \\
\text { Category }\end{array}$ & \multicolumn{2}{|c|}{$\begin{array}{c}0.67 \\
\text { Medium }\end{array}$} & \multicolumn{2}{|c|}{$\begin{array}{c}0.48 \\
\text { Medium } \\
\end{array}$} \\
\hline
\end{tabular}

Table 6. Pretest-posttest assessment data capability process dimension of science literacy

\begin{tabular}{|c|c|c|c|c|}
\hline \multirow{3}{*}{ Description } & \multicolumn{2}{|c|}{ Experiment Group } & \multicolumn{2}{|c|}{ Control Group } \\
\hline & Pretest & Posttest & Pretest & Posttest \\
\hline & \multicolumn{2}{|c|}{ Process } & \multicolumn{2}{|c|}{ Process } \\
\hline Mean & 41 & 69 & 35 & 41 \\
\hline Standard deviation & 7.89 & 10.13 & 10.05 & 15.75 \\
\hline Maximum value & 41 & 95 & 43 & 76 \\
\hline Minimum value & 1 & 18 & 13 & 20 \\
\hline $\begin{array}{l}\text { Gain } \\
\text { Category }\end{array}$ & \multicolumn{2}{|c|}{$\begin{array}{c}0.47 \\
\text { Medium }\end{array}$} & \multicolumn{2}{|c|}{$\begin{array}{l}\text { 0.10 } \\
\text { Low }\end{array}$} \\
\hline
\end{tabular}

Based on data from the pretest-posttest at the table. it can be seen that the average value of the dimensions of the process in the experimental group increased by 28 from 41 to 69 while the control group increased by 6 on a pretest-posttest from 35 to 41 . A comparison of the value of pretest-posttest between the experimental group and the control group on the dimension of the content and process can be seen in Figure 7 and 8 . 


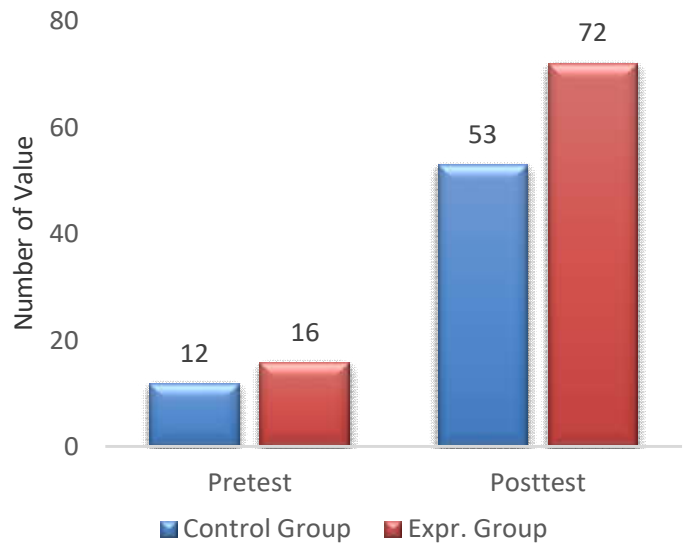

Figure 7. Results pretest-posttest control group and the experimental group dimensions of the content

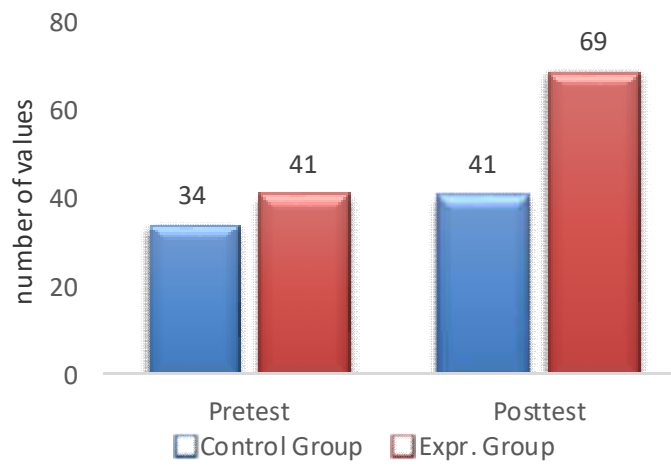

Figure 8. Results pretest-posttest control group and the experimental group dimensions of the process
Figure 7 and 8 shows that the tendency to increase the dimensions of the content and process of scientific literacy in the experimental group or the control group had a difference and increase respectively. Both groups experienced an increase after being given a different treatment both conventional learning and using e-module development results. It can be evidenced by the gain on the dimension content of the experimental group to 0.67 in the medium category and control group with a value of 0.48 gain in the medium category. The gain on the dimension process of the experimental group to 0.47 in the medium category and a control group with a value of 0.10 gain in the low category.

The next test inferential statistical analysis is to determine the relationship of the dimensions of scientific literacy improvement process with the use of e-module development results. The first step taken was to determine the normality of the data distribution that is normally distributed or not and determine homogeneity of variance.

The Normality distribution data used the chi-square analysis discretion $(\mathrm{N})<50$. Results of calculations using Microsoft Excel 2010 can be seen in Table 7.

Variant homogeneity test was performed using Levene test output results Statistics using SPSS version 23 gives the figure of significance such as Table 8 .

Table 7. Results of data normality test

\begin{tabular}{llccc}
\hline Research group & Variable & $\boldsymbol{X}^{2}$ count & $\boldsymbol{X}_{\text {table }}(\boldsymbol{a}=5 \%)$ & Conclusion \\
\hline \multirow{2}{*}{ Exp. group } & Content & -33.553 & 7.815 & Normally distributed data for \\
& Process & -26.224 & & \\
Control group & Content & -28.930 & 7.815 & Normally distributed data for \\
\hline
\end{tabular}

Table 8. Results of homogeneity of variance

\begin{tabular}{cccc}
\hline Variable & Levene Statistic & Sig. & Variants \\
\hline Content & 0.008 & 0.929 & Homogeneous \\
Process & 1.312 & 0.264 & Homogeneous \\
\hline
\end{tabular}

Based on Table 8 , it can be seen that the process variable has a homogeneous variant.

According to Triton (2006), when the value of $F$ statistic of Pillai's trace. Wilks's lambda. Hotelling's trace and Roys Reviews largest root significance smaller than 0.05 [13]. Then there is a difference in the ability of science literacy dimension process on students who use the e-module interactive physics of developing the company's results. However, if the significance is greater than 0.05 there is no difference. Test Results Multivariate analysis presented in the Table 9 . 
Table 9. Results of multrivariate test

\begin{tabular}{|c|c|c|c|}
\hline Effect & Statistical & $\mathbf{F}$ & Sig \\
\hline \multirow{4}{*}{$\begin{array}{l}\text { E-Module Interactive } \\
\text { SETS Physics approach } \\
\text { Technology and Society) }\end{array}$} & Pillai's Trace & 22.953 & 0.000 \\
\hline & Wilk's Lambda & 22.953 & 0.000 \\
\hline & Hotelling's Trace & 22.953 & 0.000 \\
\hline & Roy's Largest Root & 22.953 & 0.000 \\
\hline
\end{tabular}

According to the Table 9, the value of $F$ to the four tests has significantly less than 0.05 then $\mathrm{H}_{0}$ is rejected. There are differences in the ability of science literacy dimension in the process of students using e-physics interactive module development results.
Further test subjects is to examine the independent variables to each dependent variable. MANOVA analysis results presented in Table 10.

Table 10. Effect of Inter-Subject Test Results

\begin{tabular}{cccc}
\hline Source & Dependent Variable & F & Sig. \\
\hline E-Module Interactive Physics Approach & Content & 28.294 & 0.000 \\
Using SETS & Process & 24597 & 0.000 \\
\hline
\end{tabular}

According to Table 10. It shows that the value of $\mathrm{F}$ on the dependent variable has more significance than 0.05 . This indicates that there is the effect in using ephysics interactive module on the dependent variable of the development of scientific literacy dimension content and process.

\section{Conclusion}

Electronic modules have been produced using the SETS approach through expert validation and physics teacher with an average percentage of $96.36 \%$ making it feasible and can be used as teaching materials for high school students class XII. Science literacy skills measured dimensions of the content and process to see the difference between the experimental group using emodule interactive physics using SETS approach and control groups were studied using the textbook class XII SMA Taman Mulia Kuburaya. Gain value of the dimension experimental group 0.47 in the medium category and gain control group scored 0.10 in the low category. The learning model approach to electronics module SETS experience faces some difficulties in implementation because of the relationship with the environment indirectly. On implementation, the students are given examples of the application environment based solely on video and pictures and then the students still have to think back to guessing events. In fact, every student has the process of thinking different and so we need the implementation of a real learning environment. In the reference, a number of examples have been given which are often used by international journals. Feel free to make use of them.

It is expected that for further research the development of e-modules uses different material in an effort to improve the quality of education, especially student scientific literacy. E-module development can then use the latest application base so that the display and navigation look better and more interactive

\section{Reference}

[1] A. W. Subiantoro, "Pentingnya Praktikum dalam Pembelajaran IPA," 2010.

[2] M. Arohman and D. Priyandoko, "Kemampuan Literasi Sains Siswa pada Pembelajaran Ekosistem," 2016.

[3] A. Binadja, Pedoman Praktis Pengembangan Bahan Pembelajaran Bervisi dan Berpendekatan SETS. 2007.

[4] P. Anna, "STEM Education: Inovasi dalam Pembelajaran Sains," in Prosiding Seminar Nasional Pendidikan Sains, 2016, pp. 23-34.

[5] A. R. Hardisty et al., "BioVeL: A Virtual Laboratory for Data Analysis and Modelling in Biodiversity Science and Ecology," BMC Ecol., vol. 16, no. 1, 2016, doi: 10.1186/s12898-016-0103-y.

[6] U. et al. Toharudin, Membangun Literasi Sains Peserta Didik. 2011.

[7] OECD, PISA 2015 Assessment and Analytical Framework: Science, Reading, Mathematic and Financial Literacy,. Paris: OECD Publishing.S. Verdu, Multi-user detection, Cambridge University Press, 2015.

[8] Rusman, "Belajar Berbasis Komputer, Pembelajaran Mengembangkan Profesionalisme Abad 21," Bandung Alf., 2013.

[9] Gall, M. D, Gall, J. P, Borg, and W. R, Educational Research, An Introduction (Seventh Ed). Boston: Allyn and Bacon, 2003.

[10] L. Rizkita, H. Suwono, and H. Susilo, "Analisis Kemampuan Awal Literasi Sains Siswa SMA Kota Malang," in Prosiding Seminar Nasional II, 2016, no. 2, pp. 771-781.

[11] N. G. Laderman, J. S. Laderman, and A. Antink, "Nature of Science and Scientific Literacy," Int. J. Educ. Math. Sci. Technol. Int. Journla Educ. Math. Sci. Technol., vol. 1, no. 3, pp. 138-147, 2013.

[12] Sugiono, Metode Penelitian Kuantitatif, Kualitatif dan $R$ $\& D$, vol. 2. Bandung: Alfa Betta, 2013.

[13] R. R Hake, "Analyzing Change/Gain Scores," Unpubl. URL http//www. physics. indiana. edu/ sdi/AnalyzingChange-Gain. pdf, pp. 1-4, 1985. 